\title{
High genetic variation among Aschersonia placenta (Clavicipitaceae) isolates from citrus orchards in China
}

\author{
P.P. Wang ${ }^{1,2}$, X.H. Song ${ }^{1,3}$ and H.Y. Zhang ${ }^{1}$ \\ ${ }^{1}$ State Key Laboratory of Agricultural Microbiology, \\ Institute of Urban and Horticultural Pests, \\ College of Plant Science and Technology, Huazhong Agricultural University, \\ Wuhan, Hubei, China \\ ${ }^{2}$ College of Food Science and Engineering, Wuhan Polytechnic University, \\ Wuhan, Hubei, China \\ ${ }^{3}$ Chongqing Academy of Chinese Materia Medica, Chongqing, China \\ Corresponding author: H.Y. Zhang \\ E-mail: hongyu.zhang@mail.hzau.edu.cn
}

Genet. Mol. Res. 12 (4): 6192-6202 (2013)

Received November 1, 2012

Accepted April 16, 2013

Published December 4, 2013

DOI http://dx.doi.org/10.4238/2013.December.4.6

\begin{abstract}
Aschersonia placenta had been recognized as an important fungal pathogen of whiteflies. In recent years, natural occurrence of Aschersonia in whitefly populations was observed in many citrus orchards in the southern regions of China. We analyzed $60 \mathrm{~A}$. placenta isolates obtained from Chinese citrus orchards, using inter-simple sequence repeats to examine the genetic diversity and to determine whether intraspecific variation is correlated with geographic origin. One hundred and fourteen fragments were generated from these isolates; 97\% were polymorphic. The Nei's gene diversity $(H)$ was estimated to be 0.1748 within the populations (range 0.0974-0.2179) and 0.3057 at the species level. Analysis of molecular variance showed that the genetic variation was found mainly within populations $(74.9 \%)$. The coefficient of gene
\end{abstract}


differentiation $\left(G_{\mathrm{ST}}=0.4315\right)$ indicated that $56.85 \%$ of the genetic diversity resided within populations. The Mantel test revealed no significant correlation between the genetic distance and the corresponding geographical distance $(\mathrm{r}=0.142$ and $\mathrm{P}=0.887)$; the unweighted pair-group method using arithmetic average clustering gave similar results.

Key words: Aschersonia placenta; ISSR; Genetic diversity; China

\section{INTRODUCTION}

Entomopathogenic fungi of the genus Aschersonia are found growing on whiteflies and scale insects, and are common in tropical regions, particularly in moist old-growth forests and citrus orchards (Chaverri et al., 2008). Species in Aschersonia, such as A. aleyrodis and A. placenta, invade their hosts by actively penetrating the cuticle and have been recognized as an important fungal pathogen of whiteflies (Fransen et al., 1987; Faria and Wraight, 2001; Charnley and Collins, 2007). A. placenta (teleomorph: Hypocrella raciborskii) has flattened anamorphic stromata composed of loose hyphal tissue and wide hypothallus, possesses conidiomata with very wide openings and confluent conidial masses, and is distributed in China, India, Indonesia, Malaysia, Thailand, Cameroon, Ghana, New Guinea, the Philippines, and Vietnam (Chaverri et al., 2005; Liu et al., 2006). Former research has revealed that $A$. placenta is highly pathogenic to Bemisia argentifolii and Trialeurodes vaporariorum (Meekes et al., 2002; Wang et al., 2013). The natural occurrence of $A$. placenta in whitefly populations has been observed in many provinces in China (Zhang and Li, 2012; Wang et al 2013). It has shown a perfect natural infection rate of Aleurotrachelus camelliae in the forest (He et al., 2011) and high infection effect of Dialeurodes citri in citrus orchards in China (Tong, 1992; Zhang and Li, 2012). However, few studies investigating A. placenta resources against whiteflies in the laboratory and field were reported in recent years, and molecular studies of A. placenta resources in China were less.

With the development of molecular techniques, molecular markers have been widely used to study the genetic characteristics of entomopathogenic fungi. Molecular characterization is considered to be import for better understanding population structure, isolate typing, ecology, and usefulness in the selection of a suitable fungal biocontrol agent (Han et al., 2002; Aquino de Muro et al., 2005; Wang et al., 2005). Random amplified polymorphic DNA (RAPD) markers have been used to investigate relationships between Aschersonia species and isolates (Oborník et al., 1999). In recent years, molecular phylogenetic analyses based on some genetic loci, such as large subunit nuclear ribosomal DNA (LSU), translation elongation factor $1-\alpha(\mathrm{TEF} 1-\alpha)$, RNA polymerase II subunit 1 (RPB1), RNA polymerase unit II (RPB2), mitochondrial small subunit rDNA (mtSSU), $\beta$-tubulin and internal transcribed spacer (ITS) sequences, were conducted to determine the relationships of new species to other species of Hypocrella/Aschersonia (Chaverri et al., 2005; Liu and Hodge, 2005; Liu et al., 2005; Torres et al., 2007; Mongkolsamrit et al., 2009 ) and to examine whether some techniques were helpful in the classification of species with morphological characters (Liu et al., 2006; Chaverri et al., 2008). Although the phylogeny of $A$. placenta has been studied by a few researchers, the genetic diversity and 
population structure of $A$. placenta remain unknown. Characterizing the genetic diversity of $A$. placenta is useful for screening native isolates as whitefly biological agents.

Inter-simple sequence repeat (ISSR) markers, which have the advantage over RAPDs by employing longer primers that improve reproducibility (Godwin et al., 1997) and are more rapid and economical compared to using the amplified fragment length polymorphism (AFLP) technique (Bornet and branchard 2001), have been widely used to reveal the genetic diversity of fungi, such as the entomopathogenic fungus beauveria bassiana (Aquino de Muro et al., 2005; Wang et al., 2005), the plant pathogenic fungus Corynespora cassiicola (Nghia et al., 2008), Schistosoma japonicum isolates (Zhao et al., 2009), and Fusarium poae isolates (Dinolfo et al., 2010). These studies demonstrated that ISSR may be used as robust molecular markers for studying the population genetics of entomopathogenic fungi. ISSR marker technology was employed in this study to probe the genetic diversity of native $A$. placenta populations. The objectives were to investigate the genetic variation among $A$. placenta isolates and to examine whether intraspecific variation could be correlated with geographical origin.

\section{MATERIAL AND METHODS}

\section{Fungal samples}

The Aschersonia isolates were obtained from naturally infected whitefly nymphs on citrus leaves collected from the main citrus-planting areas in China. Sixty isolates of A. placenta were collected from 9 provinces of the southern area, namely Hunan, Jiangxi, Zhejiang, Fujian, Guangdong, Guangxi, Hubei, Chongqing, and Sichuan. They were divided into 13 populations according to the different ecological environments of the citrus plantations. Detailed information about the origin of the fungal isolates is presented in Table 1 . The isolates were cultivated on potato dextrose agar (PDA) at $25^{\circ} \mathrm{C}$ and $75 \%$ relative humidity ( $\mathrm{RH})$. The species were identified as A. placenta based on morphological characters.

\section{DNA extraction}

The mycelia used for DNA extraction were grown on PDA with cellophane at $25^{\circ} \mathrm{C}$. A total of $150 \mathrm{mg}$ mycelia were collected and homogenized in liquid nitrogen, and the mycelial powder, was suspended in $500 \mu \mathrm{L}$ CTAB extraction buffer $(100 \mathrm{mM}$ Tris- $\mathrm{HCl}, \mathrm{pH} 8,20 \mathrm{mM}$ EDTA, $\mathrm{pH} 8,2 \% \mathrm{CTAB}, 1.4 \mathrm{M} \mathrm{NaCl}$ and $1 \% \beta$-mercaptoethanol]. After incubation at $65^{\circ} \mathrm{C}$ for $1 \mathrm{~h}, 550 \mu \mathrm{L}$ phenol:chloroform:isoamyl alcohol (25:24:1) were added, and the mixture was centrifuged at $12,000 \mathrm{rpm}$ for $10 \mathrm{~min}$ at $4^{\circ} \mathrm{C}$. The aqueous layer was precipitated with isopropanol, and the DNA pellet was washed with $70 \%$ ethanol and resuspended in TE buffer (10 mM Tris-HCl, pH 8, and $1 \mathrm{mM}$ EDTA, pH 8), containing $20 \mu \mathrm{g} / \mathrm{mL}$ RNase. All DNA samples were stored at $-20^{\circ} \mathrm{C}$ until further use.

\section{ISSR amplification}

The ISSR primers were synthesized by GenScript Corporation (Nanjing, China); forty 
ISSR primers were used in this study. The amplification reactions were performed in a $25-\mu \mathrm{L}$ reaction mixture containing $2.5 \mu \mathrm{L}$ 10X PCR buffer (Sunny Biotech, Shanghai, China), 1.5 $\mathrm{mM} \mathrm{MgCl}{ }_{2}$ (Sunny Biotech, Shanghai, China), $0.16 \mathrm{mM}$ dNTP mixture, $0.4 \mathrm{mM}$ each ISSR primer, 2.5 U Taq DNA polymerase (Dongsheng Biotech, Guangzhou, China), and $20 \mathrm{ng}$ template DNA. PCR was performed as follows: an initial denaturation temperature of $94^{\circ} \mathrm{C}$ for $2 \mathrm{~min}$; 10 cycles of $94^{\circ} \mathrm{C}$ for $45 \mathrm{~s}, 50-54^{\circ} \mathrm{C}$ (depending on the primers, Table 1), which was decreased by $0.5^{\circ} \mathrm{C}$ in each cycle, for $45 \mathrm{~s}$, and $72^{\circ} \mathrm{C}$ for $1.5 \mathrm{~min}$; another 25 cycles of $94^{\circ} \mathrm{C}$ for $45 \mathrm{~s}, 45-49^{\circ} \mathrm{C}$ for $45 \mathrm{~s}$ and $72^{\circ} \mathrm{C}$ for $1.5 \mathrm{~min}$; and a final elongation of $72^{\circ} \mathrm{C}$ for $10 \mathrm{~min}$. The amplified products were detected on $1.2 \%$ agarose gels using $0.5 \mathrm{X}$ TBE buffer $(45 \mathrm{mM}$ Tris and $1 \mathrm{mM}$ EDTA) at room temperature. The gels were stained with ethidium bromide, visualized under UV light and photographed using a gel documentation system.

\section{Data analysis}

All clearly detectable ISSR product bands were scored for their presence (1) or absence (0). All amplifications were repeated at least twice and only reproducible and welldefined bands were considered for analysis. The polymorphic information content (PIC) value was calculated by an online tool (PICcalc, 2012). The binary matrix was subjected to statistical analyses using the Numerical Taxonomy Multivariate Analysis System (NTSYS-pc), version 2.10 (Rohlf, 1999). The corresponding dendrogram was constructed using unweighted pair-group method with arithmetic mean (UPGMA). The Winboot software (Yap and Nelson, 1996) was used for a bootstrap analysis with 1000 replicates to obtain the confidence of branches of the cluster tree. The genetic diversity of the populations was analyzed using POPGENE version 1.31 (Yeh et al., 1997) to determine the observed number of alleles $\left(N_{\mathrm{A}}\right)$, the effective number of alleles $\left(N_{\mathrm{E}}\right)$, Nei's gene diversity $(H)$, Shannon's index $(I)$, percentage of polymorphic bands (PPB), and Nei's genetic differentiation index between populations $\left(G_{\mathrm{ST}}\right)$. The analysis of molecular variance (AMOVA) program version 1.55 (Excoffier et al., 1992) was used to determine the genetic structure and variance between and within the populations. The significance of the variance components was determined using 1000 permutation tests. The correlation between Nei's genetic distance (Nei, 1978) and the logarithm of the geographical distance was tested with a Mantel test (Mantel, 1967). A matrix correlation coefficient (r) and one-tailed $\mathrm{P}$ value were determined using 1000 random permutations.

\section{RESULTS}

\section{ISSR amplification}

Forty ISSR primers were screened and 12 reproducible and distinct primers were selected to investigate the genetic diversity of $13 \mathrm{~A}$. placenta populations from 3 geographical regions (according to the division of optimum environment for citrus plantation in China) (Table 1). The size of the amplified fragments ranged from 300 to $2800 \mathrm{bp}$, and the polymorphic bands of the primers ranged from 6 to 12 bands (Table 2). With an average of 9.5 bands per primer, a total of 114 bands were generated, and 111 bands $(97.37 \%)$ of these were polymorphic. The mean PIC for the primers was 0.372 , with a range of 0.365 to 0.375 . A representative ISSR profile from the primer A5 is shown in Figure 1. 
Table 1. Detailed information of Aschersonia placenta populations used in this study.

\begin{tabular}{|c|c|c|c|c|c|c|}
\hline $\begin{array}{l}\text { Geographical } \\
\text { group }\end{array}$ & Population & $\begin{array}{l}\text { Sample } \\
\text { number }\end{array}$ & $\begin{array}{c}\text { Collection } \\
\text { date }\end{array}$ & $\begin{array}{l}\text { Geographic origin } \\
\text { locality/province }\end{array}$ & Longitude & Latitude \\
\hline \multirow[t]{4}{*}{$\overline{\mathrm{G} 1}$} & YW & 5 & $6 / 2009$ & Yaowan/Hubei & $111^{\circ} 18^{\prime} \mathrm{E}$ & $30^{\circ} 42^{\prime} \mathrm{N}$ \\
\hline & WD & 3 & $4 / 2009$ & Wangdian/Hubei & $111^{\circ} 40^{\prime} \mathrm{E}$ & $30^{\circ} 42^{\prime} \mathrm{N}$ \\
\hline & $\mathrm{CD}$ & 5 & $9 / 2009$ & Chengdu/Sichuan & $104^{\circ} 03^{\prime} \mathrm{E}$ & $30^{\circ} 39^{\prime} \mathrm{N}$ \\
\hline & $\mathrm{CQ}$ & 3 & $8 / 2009$ & Beibei/Chongqing & $106^{\circ} 15^{\prime} \mathrm{E}$ & $29^{\circ} 17^{\prime} \mathrm{N}$ \\
\hline \multirow[t]{4}{*}{$\mathrm{G} 2$} & JS & 4 & $8 / 2009$ & Majingao/Hunan & $109^{\circ} 48^{\prime} \mathrm{E}$ & $28^{\circ} 24^{\prime} \mathrm{N}$ \\
\hline & $\mathrm{YZ}$ & 4 & $9 / 2009$ & Yizhang/Hunan & $112^{\circ} 56^{\prime} \mathrm{E}$ & $25^{\circ} 24^{\prime} \mathrm{N}$ \\
\hline & $\mathrm{GZ}$ & 3 & $8 / 2009$ & Ganzhou/Jiangxi & $114^{\circ} 56^{\prime} \mathrm{E}$ & $25^{\circ} 49^{\prime} \mathrm{N}$ \\
\hline & NF & 4 & $8 / 2009$ & Nanfeng/Jiangxi & $116^{\circ} 31^{\prime} \mathrm{E}$ & $27^{\circ} 13^{\prime} \mathrm{N}$ \\
\hline \multirow[t]{5}{*}{ G3 } & $\mathrm{QZ}$ & 5 & $8 / 2009$ & Quzhou/Zhejiang & $118^{\circ} 52^{\prime} \mathrm{E}$ & $28^{\circ} 56^{\prime} \mathrm{N}$ \\
\hline & $\mathrm{HY}$ & 3 & $9 / 2009$ & Taizhou/Zhejiang & $121^{\circ} 16^{\prime} \mathrm{E}$ & $28^{\circ} 39^{\prime} \mathrm{N}$ \\
\hline & $\mathrm{YC}$ & 6 & $9 / 2009$ & Yongchun/Fujian & $118^{\circ} 17^{\prime} \mathrm{E}$ & $25^{\circ} 19^{\prime} \mathrm{N}$ \\
\hline & $\mathrm{ZH}$ & 8 & $8 / 2009$ & Pingyuan/Guangdong & $115^{\circ} 49^{\prime} \mathrm{E}$ & $25^{\circ} 39^{\prime} \mathrm{N}$ \\
\hline & BS & 7 & $10 / 2009$ & Baisha/Guangxi & $110^{\circ} 25^{\prime} \mathrm{E}$ & $24^{\circ} 48^{\prime} \mathrm{N}$ \\
\hline
\end{tabular}

\begin{tabular}{|c|c|c|c|c|c|}
\hline Primer No. & Sequences $\left(5^{\prime} \rightarrow 3^{\prime}\right)$ & $\operatorname{Tm}\left({ }^{\circ} \mathrm{C}\right)$ & No. of fragments amplified & No. of polymorphic fragments & PIC value \\
\hline A5 & $(\mathrm{GA})_{8} \mathrm{C}$ & 57 & 12 & 12 & 0.371 \\
\hline A7 & $(\mathrm{CA})_{8}^{8} \mathrm{G}$ & 57 & 6 & 5 & 0.375 \\
\hline A8 & $(\mathrm{AC})_{8} \mathrm{~T}$ & 55 & 9 & 8 & 0.365 \\
\hline $\mathrm{A} 10$ & $(\mathrm{AC})_{8}^{8} \mathrm{G}$ & 57 & 8 & 8 & 0.375 \\
\hline A12 & $(\mathrm{AG})_{8} \mathrm{YC}$ & 58 & 7 & 7 & 0.375 \\
\hline A15 & $(\mathrm{GA})_{8}^{8} \mathrm{YC}$ & 58 & 10 & 8 & 0.366 \\
\hline A26 & $\mathrm{HBH}(\mathrm{AG})_{7}$ & 57 & 9 & 9 & 0.369 \\
\hline A30 & $(\mathrm{AG})_{8} \mathrm{TC}$ & 58 & 10 & 10 & 0.373 \\
\hline A 31 & $(\mathrm{GA})_{6}^{8} \mathrm{GG}$ & 53 & 9 & 9 & 0.375 \\
\hline A34 & $(\mathrm{GTC})_{6}$ & 65 & 12 & 12 & 0.374 \\
\hline A36 & $\mathrm{CGC}(\mathrm{CT})_{7}$ & 60 & 12 & 12 & 0.375 \\
\hline A 38 & $(\mathrm{CTC})_{4} \mathrm{GC}$ & 59 & 10 & 10 & 0.365 \\
\hline
\end{tabular}

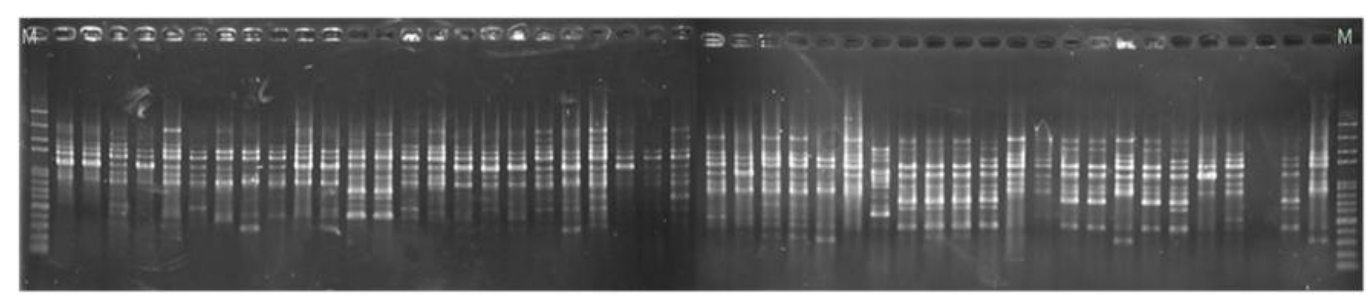

Figure 1. Representative ISSR profile of 46 A. placenta isolates with primers (GA) ${ }_{8} \mathrm{C}$. Lane $M=$ molecular size marker.

\section{Genetic diversity revealed by ISSR}

The genetic diversity of 13 Aschersonia placenta populations is presented in Table 3. The average $N_{\mathrm{E}}$ per locus was 1.3038 . The percentage of polymorphic bands (PPB) ranged from 23.68 to $63.16 \%$, with an average of $47.37 \%$. Nei's genetic diversity $(H)$ ranged from 0.0974 and 0.2179 , with an average of 0.1748 at the population level. Shannon's information index $(I)$ varied between 0.1416 and 0.3302 , with an average of 0.2595 at the population level. The genetic diversity of all populations and 3 groups are shown in Table 4. At the species level, Nei's 
genetic diversity $(H=0.3057)$ and Shannon's information index $(I=0.4667)$ demonstrated a relatively high level of genetic diversity. Nei's total genetic diversity $\left(H_{\mathrm{T}}\right)$, within population genetic diversity $\left(H_{\mathrm{S}}\right)$, coefficient of genetic differentiation $\left(G_{\mathrm{ST}}\right)$ and gene flow $\left(N_{\mathrm{m}}\right)$ were $0.3074,0.1748,0.4315$, and 0.6587 , respectively. The polymorphic loci and percentage of polymorphic loci of 3 groups were less than those of the overall populations. In each group, relatively low $\mathrm{G}_{\mathrm{ST}}$ indicated that the genetic diversity between populations was less than that within populations within the group. The gene flow of the 3 groups was relatively higher than that of all populations.

\begin{tabular}{|c|c|c|c|c|c|}
\hline Populations & $N_{\mathrm{A}}$ & $N_{\mathrm{E}}$ & $H$ & $I$ & PPB (\%) \\
\hline YW & 1.4912 & 1.3050 & 0.1758 & 0.2624 & 49.12 \\
\hline WD & 1.2456 & 1.1973 & 0.1066 & 0.1529 & 24.56 \\
\hline JS & 1.5965 & 1.3650 & 0.2143 & 0.3210 & 59.65 \\
\hline YZ & 1.6316 & 1.3602 & 0.2179 & 0.3302 & 63.16 \\
\hline GZ & 1.2368 & 1.1751 & 0.0974 & 0.1416 & 23.68 \\
\hline $\mathrm{NF}$ & 1.4474 & 1.3083 & 0.1740 & 0.2557 & 44.74 \\
\hline QZ & 1.5614 & 1.3756 & 0.2111 & 0.3112 & 56.14 \\
\hline HY & 1.4298 & 1.3037 & 0.1718 & 0.2515 & 42.98 \\
\hline YC & 1.5965 & 1.3417 & 0.2004 & 0.3027 & 59.65 \\
\hline $\mathrm{ZH}$ & 1.6140 & 1.3532 & 0.2079 & 0.3134 & 61.40 \\
\hline BS & 1.5175 & 1.3117 & 0.1806 & 0.2700 & 51.75 \\
\hline $\mathrm{CD}$ & 1.5526 & 1.3635 & 0.2120 & 0.3134 & 55.26 \\
\hline CQ & 1.2368 & 1.1889 & 0.1024 & 0.1470 & 23.68 \\
\hline Average & 1.4737 & 1.3038 & 0.1748 & 0.2595 & 47.37 \\
\hline
\end{tabular}

$N_{\mathrm{A}}=$ observed number of alleles; $N_{\mathrm{E}}=$ effective number of alleles; $H=$ Nei's (1973) gene diversity; $I=$ Shannon's information index; $\mathrm{PPB}=$ percentage of polymorphic bands.

Table 4. Comparison of genetic diversity estimates in 13 Aschersonia placenta populations and 3 geographical groups.

\begin{tabular}{lcccc}
\hline Population & All populations & Group 1 & Group 2 & Group 3 \\
\hline Number of polymorphic loci & 111 & 84 & 97 & 106 \\
Percentage of polymorphic loci $(\%)$ & 97.37 & 73.689 & 85.09 & 92.98 \\
Nei's genetic diversity $(H)$ & 0.3057 & 0.2678 & 0.2880 & 0.2933 \\
Shannon's information index $(I)$ & 0.4667 & 0.3983 & 0.4329 & 0.4502 \\
Total gene diversity $\left(H_{\mathrm{T}}\right)$ & 0.3074 & 0.2638 & 0.2852 & 0.2999 \\
Gene diversity within populations $\left(H_{\mathrm{S}}\right)$ & 0.1748 & 0.1492 & 0.1759 & 0.1943 \\
Gene differentiation $\left(G_{\mathrm{ST}}\right)$ & 0.4315 & 0.4343 & 0.3833 & 0.3520 \\
Gene flow $\left(N_{\mathrm{m}}\right)$ & 0.6587 & 0.6512 & 0.8045 & 0.9204 \\
\hline
\end{tabular}

\section{Genetic variation and relationships}

AMOVA analysis (Table 5) showed that the genetic differentiation between and within the populations was significant $(\mathrm{P}<0.001)$. The result $\left(\Phi_{\mathrm{ST}}=0.251 ; \mathrm{P}<0.001\right)$ indicated that most of the variation was due to genetic differences within populations $(74.93 \%)$ and $25.07 \%$ of the variation was partitioned between populations. When the genetic variation was assessed according to geographical regions, a large proportion of genetic variation $(95.10 \%)$ existed between individuals within geographical regions, and only $4.90 \%$ of total genetic variability occurred between the three geographical regions. The coefficient of gene differentiation $\left(G_{\mathrm{ST}}\right)$ was 0.432 , which also indicated a low level of population differentiation.

A Mantel test revealed that there was no significant correlation between the observed 
genetic distance and the calculated geographical distance $(\mathrm{r}=0.142$ and $\mathrm{P}=0.887)$.

UPGMA cluster analysis showing the genetic relationship between the $60 \mathrm{~A}$. placenta isolates is presented in Figure 2. The 60 isolates represented 59 haplotypes and were resolved into 2 clusters, with an average similarity between groups of 58\%. Cluster comprised most of the samples from 3 geographical groups, and 56 isolates clustered only partially according to their geographical origins. Cluster $\alpha$ only contained 4 isolates. Samples 6 and 8 were from group 2, while 21 and 22 were from group 3.

\begin{tabular}{|c|c|c|c|c|c|c|}
\hline Source of variation & d.f. & SSD & MSD & $\mathrm{VC}$ & TVP (\%) & $\mathrm{P}^{*}$ \\
\hline Among populations & 12 & 439.75 & 36.65 & 4.85 & 25.07 & $<0.001$ \\
\hline Within populations & 47 & 680.82 & 14.49 & 14.49 & 74.93 & $<0.001$ \\
\hline Among geographic regions & 2 & 72.69 & 36.35 & 0.95 & 4.90 & $<0.001$ \\
\hline Within geographic regions & 57 & 1047.87 & 18.38 & 18.38 & 95.10 & $<0.001$ \\
\hline
\end{tabular}

d.f. = degree of freedom; $\mathrm{SSD}=$ sum of squares; $\mathrm{MSD}=$ mean squared deviations; $\mathrm{VC}=$ variance component; TVP

$=$ total variance percentage; *significance tests after 1000 permutations.

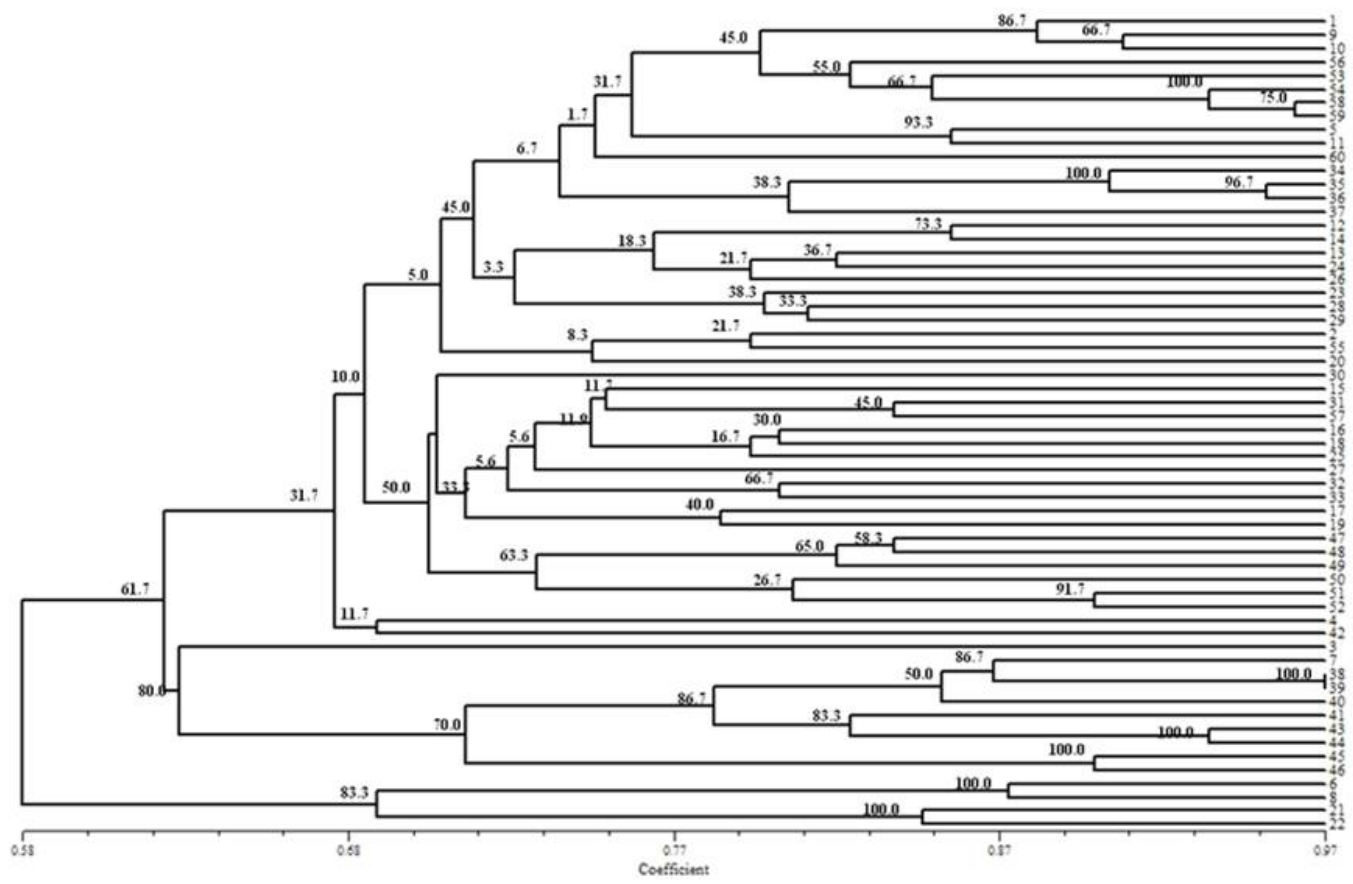

Figure 2. UPGMA-based dendrogram showing the genetic relationship among 60 Aschersonia placenta isolates, as based on Nei's genetic distance estimates obtained for ISSR markers.

\section{DISCUSSION}

In our study, the genetic diversity of 13 populations of $A$. placenta across the major distribution regions in China was analyzed by ISSR markers. The mean PIC obtained in this 
study was 0.328 , indicating that the primers were informative and useful for genetic variation studied in this research (Farsani et al., 2012). The coefficient of gene differentiation $\left(G_{\mathrm{ST}}=\right.$ 0.4315 ) and AMOVA analysis revealed that high variation resulted from genetic differences between A. placenta individuals within populations. Similar results were reported for previous studies on many species using ISSR markers, such as Orychophragmus violaceus (Zhang and Dai, 2010) and Vicia ramuliflora and V. unijuga (Han and Wang, 2010). Genetic variation is essential for a species to evolve and respond to environmental changes (Barrett and Kohn, 1991). The high level of genetic variation among the A. placenta individuals suggests that they exhibit a flexible adaptability to environmental changes.

Nei's genetic diversity $(H=0.3057)$ and Shannon's information index $(I=0.4667)$ indicated that $A$. placenta maintained a high genetic diversity at the species level. The gene diversity of fungal isolates can arise due to the diversification of a single genotype into several forms through accumulations of changes in the genome (Padmavathi et al., 2003). Taxon studies have described the morphological variation of $A$. placenta in color and size of stromata, color and the arrangement of conidial masses on the stromata, and size of conidia (Liu et al., 2006). Such descriptions indicate that the fungus can exhibit a large degree of morphological plasticity with the potential for multiple morphological expressions of individual traits. Morphological plasticity may contribute to the high genetic diversity observed in this species. The genetic diversity of fungi can also be affected by many factors such as the ecosystems from which the isolates are derived, vegetation, insect host, and changing variant habitats (Wang et al., 2005), reproduction, survival strategies and mechanism of dispersal (Castrillo and Brooks, 1998) and gene flow (Slatkin, 1987). Of the 13 populations studied, the YZ population had the highest genetic diversity $(H=0.2179, I=0.3302, \mathrm{PPB}=63.16 \%)$. The isolates of $\mathrm{YZ}$ population were collected from Yizhang county, Hunan Province. The ecosystems of Yizhang are complicated since it is surrounded on three sides by mountains higher than $1600 \mathrm{~m}$ and has many kinds of topography, such as plains, hills and mound land. Although the citrus orchards are usually distributed on the hills or mound land that are similar to other areas, the multiple and complex geographical climate may contribute to the high amount of diversity in this species. The genetic diversity of the $\mathrm{ZH}$ population from Pingyuan county of Fujian Province was also high $(H=0.2079, I=0.3134, \mathrm{PPB}=61.40 \%)$. This area has a simple topography of hilly mountains and an altitude of less than $500 \mathrm{~m}$. However, the 8 samples of this population were collected from 3 kinds of citrus plants, including pomelo, navel orange and citrus unshiu Marc. In contrast, the GZ and CQ populations showed lower genetic diversity than other populations. The reason might be that they contained fewer samples and were from citrus orchards with a simple ecosystem and single-variety plant.

The gene differentiation $\left(G_{\mathrm{ST}}\right)$ of the 3 geographical groups $(0.4343,0.3833$ and 0.3520 , respectively) indicated that the genetic diversity between populations was less than that within populations within these groups. The optimal citrus-planting ecological areas were divided into 4 geographical regions according to the topographical distribution in China. Although the topography of the 3 geographical groups (hilly land, mountain plain and basin, respectively) in the present study is different, the citrus-planting environment is similar. All samples were collected in the citrus orchards where there had been an outbreak of Dialeurodes citri in that period, so the diversity of host insects was low. The relative high gene flow $\left(N_{\mathrm{m}}\right)$ values between populations within each group (0.6512, 0.8045 and 0.9204$)$ showed that the gene exchange between $A$. placenta populations was not limited. Therefore, 
the genetic diversity of these populations was high. Previous research has reported that high levels of haplotypic diversity can be maintained in asexually reproducing fungi (Zeigler et al., 1997). The haplotypic diversity levels of $A$. placenta isolates within each population were high according to the dendrogram. All these reasons may reduce the genetic difference between populations.

Many studies have discussed the genetic relationships between entomopathogenic fungal isolates and their geographical origin. The AFLP analysis of $B$. bassiana isolated from insects and soil revealed no significant correlation between the isolates and their geographical origin (Aquino de Muro et al., 2003). The opposite conclusion made by Aquino de Muro et al. (2005) suggested that both the ISSR and AFLP analyses of B. bassiana gave indications of intraspecific groupings correlated with the geographical origin. Wang et al. (2005) also indicated that there was a certain association between $B$. bassiana isolates and their geographical origin. Similar results were obtained in many molecular analysis studies of $A$. placenta. The clustering of Aschersonia isolates coincides with their geographical origin in the RAPD-based phylogenetic tree reconstructed by Oborník et al. (1999). In contrast, the RAPD analysis of 16 Aschersonia spp isolates by Qiu et al. (2004) demonstrated a high genetic variation between the samples, but there was no association between the Aschersonia isolates and their geographical origin. Based on the analysis of previous studies, Wang et al. (2005) suggested that it is necessary to select fungal isolates from similar ecological habitats for detecting the genetic relationships between the isolates and their geographical origins. Although all A. placenta isolates were collected from citrus orchards that had similar planting environment and management strategy, the clustering analysis showed that there were no clear relationships between the $A$. placenta isolates and their geographical origin. Thus, more isolates and appropriate molecular techniques are required to obtain accurate assessments of the potential genetic relationships between isolates and their geographical origin.

In summary, our results indicated that the genetic diversity of $A$. placenta was high at the species level, and a high genetic differentiation was generally found between the isolates. Cluster analysis and the Mantel test did not reveal a significant correlation between the isolates and their geographical origin. The results suggested that gene exchange between the populations was not affected by their geographical distribution. The study of genetic variation between $A$. placenta isolates will enable us to screen highly pathogenic isolates with flexible adaptability to different citrus plantation environments for whitefly control, and to study correlations between genetic variation and other phenotypic traits, such as pathogenicity.

\section{ACKNOWLEDGMENTS}

Research supported by the Earmarked Fund for Modern Agro-Industry Technology Research System (\#CARS-27). We express our thanks to C.J. Shi, a graduate student. We also thank the citrus research centers of Hubei, Hunan, Jiangxi, Zhejiang, Guangdong, Guangxi, Fujian, Sichuan, and Chongqing Provinces.

\section{REFERENCES}

Aquino de Muro M, Mehta S and Moore D (2003). The use of amplified fragment length polymorphism for molecular analysis of Beauveria bassiana isolates from Kenya and other countries, and their correlation with host and geographical origin. FEMS Microbiol. Lett. 229: 249-257. 
Aquino de Muro M, Elliottt S, Moore D, Parker BL, et al. (2005). Molecular characterisation of Beauveria bassiana isolates obtained from overwintering sites of Sunn Pests (Eurygaster and Aelia species). Mycol. Res. 109: 294-306.

Barrett SCH and Kohn JR (1991). Genetics and Evolutionary Consequences of Small Population Size in Plants: Implications for Conservation. In: Genetics and Conservation of Rare Plants. (Falk DA and Holsinger KE, eds.). Oxford University Press, New York, 3-30.

Bornet B and Branchard M (2001). Nonanchored inter simple sequence repeat (ISSR) markers: reproducible and specific tools for genome fingerprinting. Plant. Mol. Biol. Rep. 19: 209-215.

Castrillo LA and Brooks WM (1998). Differentiation of Beauveria bassiana isolates from the darkling beetle, Alphitobius diaperinus, using isozyme and RAPD analyses. J. Invertebr. Pathol. 72: 190-196.

Charnley AK and Collins SA (2007). Entomopathogenic Fungi and Their Role in Pest Control. In: Environmental and Microbial Relationships 2nd Edition. (Kubicekand CP and Druzhinina IS, eds.). Springer-Verlag, Berlin. 159-187.

Chaverri P, Bischoff JF, Liu M and Hodge KT (2005). A new species of Hypocrella, H. macrostroma, and its phylogenetic relationships to other species with large stromata. Mycol. Res. 109: 1268-1275.

Chaverri P, Liu M and Hodge KT (2008). A monograph of the entomopathogenic genera Hypocrella, Moelleriella, and Samuelsia gen. nov. (Ascomycota, Hypocreales, Clavicipitaceae), and their aschersonia-like anamorphs in the Neotropics. Stud. Mycol. 60: 1-66.

Dinolfo MI, Stenglein SA, Moreno MV, Nicholson P, et al. (2010). ISSR markers detect high genetic variation among Fusarium poae isolates from Argentina and England. Eur. J. Plant. Pathol. 127: 483-491.

Excoffier L, Smouse PE and Quattro JM (1992). Analysis of molecular variance inferred from metric distances among DNA haplotypes: application to human mitochondrial DNA restriction data. Genetics 131: 479-491.

Faria M and Wraight SP (2001). Biological control of Bemisia tabaci with fungi. Crop. Prot. 20: 767-778.

Farsani TM, Etemadi N, Sayed-Tabatabaei BE and Talebi M (2012). Assessment of genetic diversity of bermudagrass (Cynodon dactylon) using ISSR markers. Int. J. Mol. Sci. 13: 383-392.

Fransen JJ, Winkelman K and van Lenteren JC (1987). The differential mortality at various life stages of the greenhouse whitefly, Trialeurodes vaporariorum (Homoptera: Aleyrodidae), by infection with the fungus Aschersonia aleyrodis (Deuteromycotina: Coelomycetes). J. Invertebr. Pathol. 50: 158-165.

Godwin ID, Aitken EA and Smith LW (1997). Application of inter simple sequence repeat (ISSR) markers to plant genetics. Electrophoresis 18: 1524-1528.

Han Q, Inglis GD and Hausner G (2002). Phylogenetic relationships among strains of the entomopathogenic fungus, Nomuraea rileyi, as revealed by partial beta-tubulin sequences and inter-simple sequence repeat (ISSR) analysis. Lett. Appl. Microbiol. 34: 376-383.

Han Y and Wang HY (2010). Genetic diversity and phylogenetic relationships of two closely related northeast China Vicia species revealed with RAPD and ISSR markers. Biochem. Genet. 48: 385-401.

He XY, Qiu JZ, Cai SP and Ding B (2011). Characters of Aleurotrachelus camelliae Kuwana and the natural control effect of Aschersonia placenta Berk.et Br. on it. Forest Pest. Dis. 30: 23-25.

Liu M and Hodge KT (2005). Hypocrella zhongdongii sp. nov., the teleomorph of aschersonia incrassata. Mycol. Res. 109: 818-824.

Liu M, Rombach MC, Humber RA and Hodge KT (2005). What's in a name? Aschersonia insperata: a new pleoanamorphic fungus with characteristics of Aschersonia and Hirsutella. Mycologia 97: 246-253.

Liu M, Chaverri P and Hodge KT (2006). A taxonomic revision of the insect biocontrol fungus Aschersonia aleyrodis, its allies with white stromata and their Hypocrella sexual states. Mycol. Res. 110: 537-554.

Mantel N (1967). The detection of disease clustering and a generalized regression approach. Cancer Res. 27: 209-220.

Meekes ET, Fransen JJ and van Lenteren JC (2002). Pathogenicity of Aschersonia spp. against whiteflies Bemisia argentifolii and Trialeurodes vaporariorum. J. Invertebr. Pathol. 81: 1-11.

Mongkolsamrit S, Luangsa-Ard JJ, Spatafora JW, Sung GH, et al. (2009). A combined ITS rDNA and beta-tubulin phylogeny of Thai species of Hypocrella with non-fragmenting ascospores. Mycol. Res. 113: 684-699.

Nei M (1978). Estimation of average heterozygosity and genetic distance from a small number of individuals. Genetics 89: 583-590.

Nghia NA, Kadir J, Sunderasan E, Puad AM, et al. (2008). Morphological and inter simple sequence repeat (ISSR) markers analyses of Corynespora cassiicola isolates from rubber plantations in Malaysia. Mycopathologia 166: 189-201.

Oborník M, Stouthamer R, Meeks E and Schilthuittzen M (1999). Molecular characterization and phylogeny of the entomopathogenic fungus Aschersonia sp. Plant. Protect. Sci. 35: 1-9.

Padmavathi J, UmaDevi K, Rao CU and Reddy NN (2003). Telomere fingerprinting for assessing chromosome number, isolate typing and recombination in the entomopathogen Beauveria bassiana. Mycol. Res. 107: 572-580.

PICcalc (2012). Polymorphic Information Content Calculator. Available at [http://w3.georgikon.hu/pic/english/default. aspx]. Accessed June 21, 2012. 
Qiu JZ, Huang ZP, Pan JR and Xie XQ (2004). RAPD and LSU rDNA sequence analyses of entomogenous fungus Aschersonia. J. Agricul. Biotech. 12: 578-582.

Rohlf FJ (1999). NTSYSPC: Numerical Taxonomy and Multivariate Analysis System, Version 2.10; Department of Ecology and Evaluation. State University of New York, New York.

Slatkin M (1987). Gene flow and the geographic structure of natural populations. Science 236: 787-792.

Tong YF (1992). The natural control effect of Aschersonia placenta on Dialeurodes citri (Ashmead). South. China Fruits 21: 44-45.

Torres MS, White Jr JF and Bischoff JF (2007). Hypocrella panamensis sp. nov. (Clavicipitaceae, Hypocreales): a new species infecting scale insects on Piper carrilloanum in Panama. Mycol. Res. 111: 317-323.

Wang S, Miao X, Zhao W, Huang B, et al. (2005). Genetic diversity and population structure among strains of the entomopathogenic fungus, Beauveria bassiana, as revealed by inter-simple sequence repeats (ISSR). Mycol. Res. 109: 1364-1372.

Wang PP, Song XH, Zhang HY (2013). Isolation and characterization of Aschersonia placenta from citrus orchards and its pathogenicity towards Dialeurodes citri (Ashmead). J. Invertebr. Pathol. 112:122-128.

Yap IV and Nelson RJ (1996). Winboot: A Program for Performing Bootstrap Analysis of Binary Data to Determine the Confidence Limits of UPGMA-based Dendrograms. International Rice Research Institute: Metro Manila.

Yeh FC, Yang RC and Ye ZH (1997). POPGENE, the user-friendly shareware for population genetic analysis. Molecular Biology and Biotechnology Centre. University of Alberta, Alberta.

Zeigler RS, Scott RP, Leung H, Bordeos AA, et al. (1997). Evidence of parasexual exchange of DNA in the rice blast fungus challenges its exclusive clonality. Phytopathology 87: 284-294.

Zhang LJ and Dai SL (2010). Genetic variation within and among populations of Orychophragmus violaceus (Cruciferae) in China as detected by ISSR analysis. Genet. Resour. Crop. Evol. 57: 55-64.

Zhang HY and Li HY (2012). Photographic Guide to Key Control Techniques for Citrus Disease and Insect Pests. Chinese Agricultural Press, Beijing.

Zhao GH, Li J, Zou FC, Mo XH, et al. (2009). ISSR, an effective molecular approach for studying genetic variability among Schistosoma japonicum isolates from different provinces in mainland China. Infect. Genet. Evol. 9: 903-907. 